\title{
COMPARISONS OF THE HISTOLOGICAL MORPHOLOGY AND IN VITRO PERCUTANEOUS ABSORPTION OF CAFFEINE IN SHED SNAKE SKIN AND HUMAN SKIN
}

\author{
Manuel Sacha*, Nancy Weisbach, Anna-Sophie Pöhler, Nina Demmerle, Eleonore Haltner \\ Across Barriers GmbH, Science Park 1, Saarbrücken, Germany \\ *Corresponding author, E-mail:m.sacha@acrossbarriers.de
}

\begin{abstract}
The employment of excised skin (human or animal) mounted in diffusion cells is frequently used for the characterization of biopharmaceutical properties of topical semisolids dosage forms. Reptile skin from snake appears to be a useful alternative to other animal and human skins in assessing the potential for transdermal drug delivery. The aim of the study was to compare human and snake skin from a histological point of view. Furthermore the absorption of caffeine, as a hydrophilic model substance, was compared on snake shed skins (two anatomical locations; ventral and dorsal), from three different species, Python regius, Epicrates maurus colombianus, Lampropeltis triangulum campbelli, and human skin. Snake skin shows histological similarity to human Stratum corneum in term of thickness and composition. Regarding the absorption, the cumulative amount of caffeine increased linearly with time through the dorsal and ventral shed skins of all 3 species. Except for Lampropeltis triangulum campbelliventral skin, the caffeine permeation behavior obtained on all snake shed skins evaluated was in a similar range as on human skin. One main advantage of shed skin, is that snakes molt regularly and can provide many sheds, that can be obtained without sacrificing the animals.
\end{abstract}

Key words: caffeine; transdermal; shed skin; in vitro; snake; topical formulation

\section{Introduction}

Transdermal drug delivery (TDD) is an alternative to gastrointestinal administration systems. The bypassing of the intestinal tract avoids first-pass metabolism, and can reduce the risk of toxicity and increases patient compliance. Pharmaceutical companies are focusing on the elaboration of new topical formulations. For the facilitation and shortening of the generally lengthy and resource consuming pharmaceutical development procedures, in vitro models are

Received: 19 March 2019

Accepted for publication: 21 April 2020 becoming increasingly popular $(1,2)$. Currently the tendency is the decreased interest and acceptance for animal testing (3).

In the last twenty years, the trend of the scientific community was to reduce the number of animals used in preclinical and further scientific experiments. The 3Rs (Replacement, Reduction, Refinement) guiding principle (4) try to be progressively adopted by various research institutes in order to set up animal alternatives testing methods based on cell or tissue in vitro assays. This innovative point of view is in accordance with the animal rights. But new in vitro models, which correlate as much as possible to human in vivo conditions, are still needed. Currently, in vitro 
Franz diffusion experiments have been recognized as one of the most significant tool to investigate transdermal drug administration.

According to the OECD 428 guideline (5), various excised skins, full or dermatomed, from human or animal origins can be used as biological membrane mounted in Franz diffusion cells to evaluate the absorption of molecules from topical formulations. Skin membranes can be prepared in different manners, but the most important layer, Stratum corneum (SC) representing the main barrier of the tissue, must remain intact for the investigations. Physiological buffer is recommended as acceptor medium, in order to simulate the systemic circulation. Samples are drawn at define time intervals or continuously (5).

Excised human skin is considered to be the most predictive membrane for in vitro permeation studies. But ethical considerations and scarcity of the tissue represent the main problems for the laboratories to use human skin for percutaneous absorption evaluations. Therefore, animal skins that are histologically similar to human skin, such as porcine skin (sometimes obtained from slaughterhouses), are often used as alternatives, but require sacrificing the animal (5).

Based on lipid composition as well as on thickness of the Stratum corneum, snake skin (reptile) appears to be an interesting substitute of human and further animal skins (6).

In 1988 Higuchi and Kans introduced for the first time the concept of using snake shed skin as biological barrier for in vitro percutaneous studies (7).

One major benefit of snake shed skin is that the molting process occurs regularly (e.g. once a month), providing therefore multiple sheds from a single individual. The variability between individual as it is the case in other models is excluded (8).

Further non-negligible advantage, is that the skin can be obtained without sacrificing the animals. Also, zoos in each country can make these tissues easily accessible for the laboratories. The tissue is "dead" biological material therefore storable at room temperature.

Here, we present, after a histological comparison between human and reptile skin, the results of in vitro permeation testing for snake shed skin compared to human skin using a well-established Franz cell diffusion method and caffeine as marker. Caffeine, a high permeable marker, with high biological activity properties (degradation of fat, cells protection against UV, stimulation of hair growth (9), is often included in cosmetic formulations. Furthermore this molecule is used as hydrophilic quality control molecule, in in vivo as well as in vitro absorption studies with human or animal skin (5).

It is not well known on the use of shed snake skin as a substitute for the human skin. For this purpose, shed skins (in two anatomical locations: ventral and dorsal) of three different species from three different families of snakes, Colubridae, Boidae, and Pythonidae, were compared to human skin.

\section{Material and methods}

Anhydrous caffeine (purity: $99.9 \%$, molecular weight: 194.19 g. $\mathrm{mol}^{-1}$, log P: -0.07, pKa: 10.4 at $40^{\circ} \mathrm{C}$, solubility: $21.6 \mathrm{mg} \cdot \mathrm{L}^{-1}$ at $25^{\circ} \mathrm{C}$ (10) used for the preparation of the test solution and as analytical standard was obtained from Carl Roth GmbH (Karlsruhe, Germany). PBS (phosphate buffered saline) powder without $\mathrm{Ca}^{2+}$ and $\mathrm{Mg}^{2+}$, was supplied by Biochrom GmbH (Berlin, Germany). Hematoxylin and all further reagents used for Histology were from Dako belonging to Agilent Technologies GmbH (Waldbronn, Germany).

\section{Caffeine solution for topical administration}

A caffeine solution with a concentration of approximately $10 \mathrm{mg} \cdot \mathrm{mL}^{-1}$ was prepared. The caffeine was weighed in a volumetric flask and filled up to the mark with PBS-buffer $\mathrm{pH}$ 7.4. Finally, the solution was shaken until completely dissolved.

The PBS buffer $\mathrm{pH} 7.4$ without $\mathrm{Mg}$ ions and $\mathrm{Ca}$ ions was prepared as follows: $9.55 \mathrm{~g}$ dry substance (e.g. Dulbecco's phosphate buffered saline from Biochrom) was transferred into a 1 liter volumetric flask and dissolved in $900 \mathrm{~mL}$ purified water. The $\mathrm{pH}$ value was controlled and adjusted to $7.40 \pm$ 0.05 with ortho-phosphoric acid. Afterwards the flask was filled up with purified water. The solution was degassed in an ultra-sonic bath for at least 15 minutes prior to use. The composition (according to supplier Biochrom) is as follows: $8000 \mathrm{mg} / \mathrm{L}$ $\mathrm{NaCl} ; 200 \mathrm{mg} / \mathrm{L} \mathrm{KCl} ; 1150$ mg/L Na2HPO4; 200 $\mathrm{mg} / \mathrm{L} \mathrm{KH} 2 \mathrm{PO} 4$. 
Permeation across human and snake shed skins

Human skin

This ex vivo absorption method was based on the Organisation for Economic Cooperation and Development (OECD) Test No. 428: Skin absorption: in vitro method (OECD, 2004) (5). Human abdominal skin samples from twenty three patients were obtained via surgical skin removal procedures (Dr. Pierre Sibille, reconstructive and cosmetic surgeon, Nancy, France) that were unrelated to the present investigation. Each of the twenty three patients consented to the scientific use of skin prior to surgery. Skin was not used if there was a pathologic finding, skin damage, strongly marked scarring, or pregnancy stretch marks.

The excised skin was cooled to $4^{\circ} \mathrm{C}$. Then, the subcutaneous fatty layer was separated from the skin, and the skin specimen was stored at $-20^{\circ} \mathrm{C}$ until use (less than 466 days according to the
OECD guideline 428). To prepare the skin sample for use, the specimen was thawed and cut into strips with a scalpel and dermatomed to a mean thickness of $500 \pm 100 \mu \mathrm{m}$, leaving the Stratum corneum intact.

\section{Snake shed skin}

The shed skins of three snake species from three different snake families were obtained after molting from the author's private collection (Figure 1). The three selected species were: from the Colubridae family, Lampropeltis triangulum campbelli (Lampropeltis), from the Boidae family, Epicrates maurus colombianus (Boa) and Python regius (Python) from the Pythonidae family. The tissues were not older than 2 months and stored at room temperature, under dry conditions, until preparation. Humidity condition was not controlled.

The skins were cut to size and hydrated by allowing them to soak overnight in distilled water in a covered petri dish (Figure 2) (11).

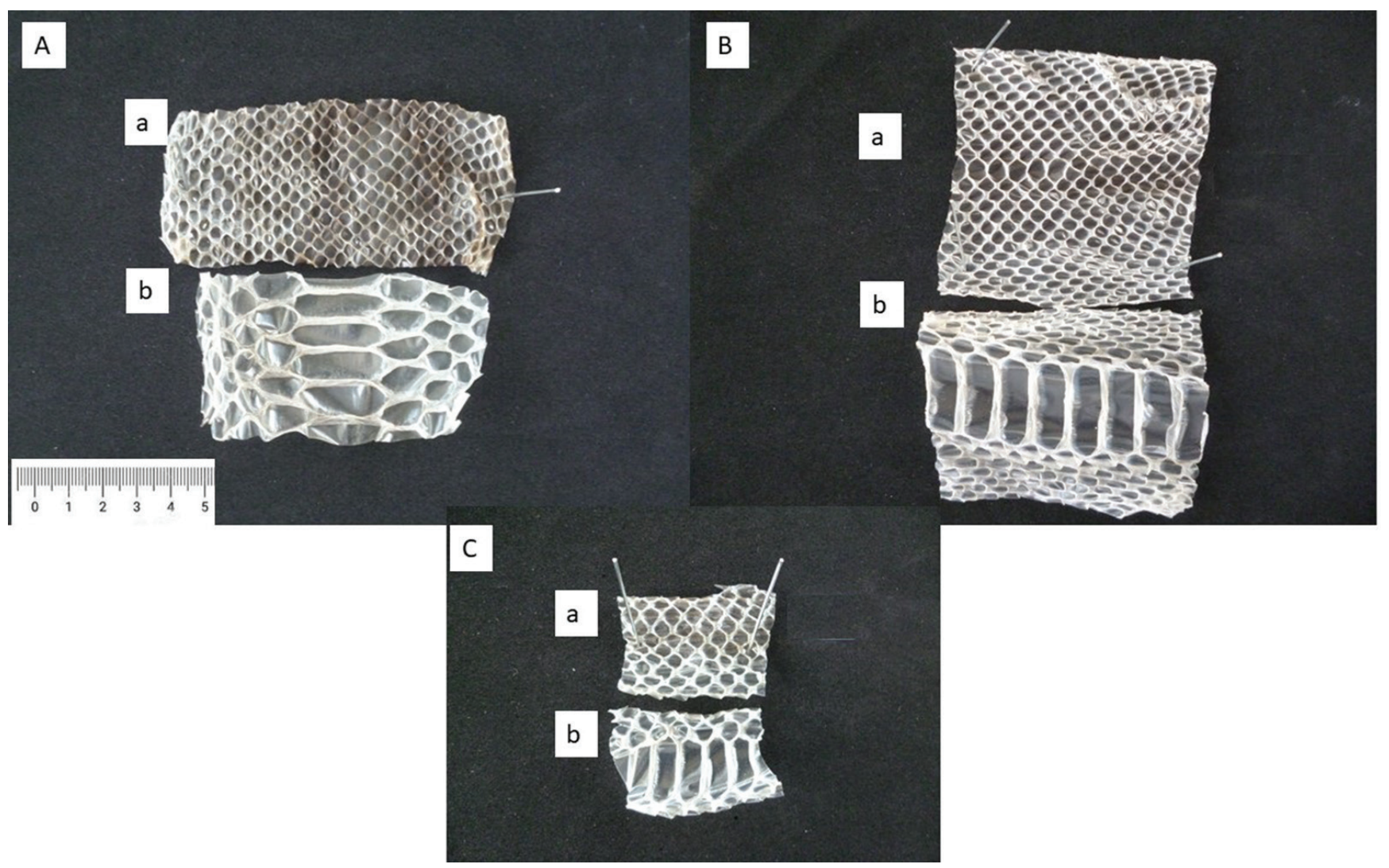

Figure 1: Photographs of the shed snake skins. A. Python regius, B. Epicrates maurus colombianus and C. Lampropeltis triangulum campbelli. a. Dorsal part, b. Ventral part 


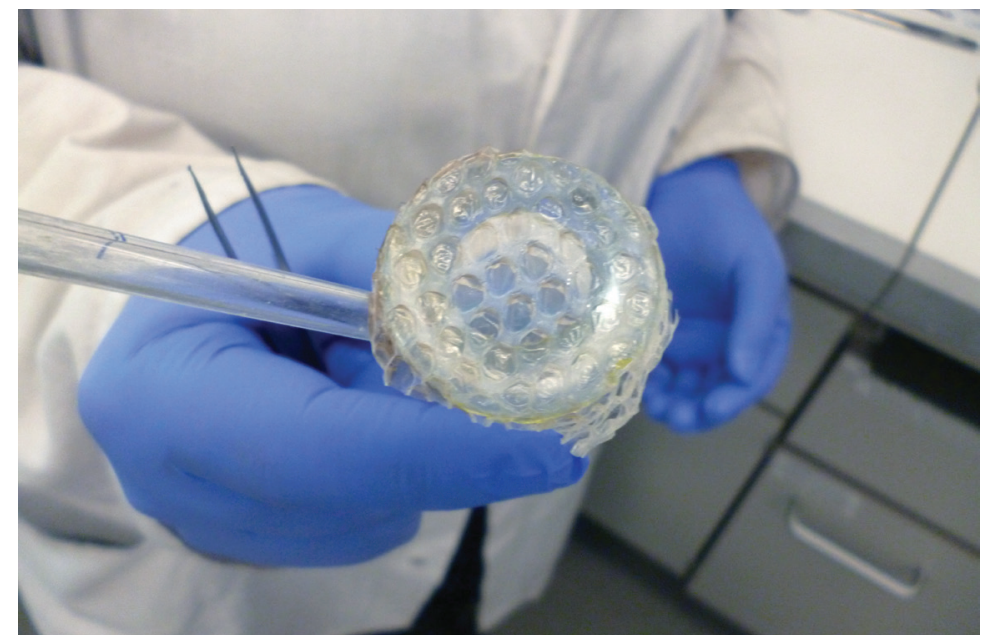

Figure 2: dorsal Python shed snake skin applied on the franz diffusion cell after overnight hydratation

\section{Franz cell}

Circular samples from each skin specimen were prepared with a hollow punch and placed between the donor and receiver sections of a Franz cell (diffusion area $1.8 \mathrm{~cm}^{2}$ ), with the Stratum corneum facing the donor cell. The receptor compartment medium was PBS pH 7.4 without $\mathrm{Mg}$ or $\mathrm{Ca}$ ions and was kept at $32 \pm 1^{\circ} \mathrm{C}$. The receptor compartment was mixed with a magnetic stir bar at $400 \mathrm{rpm}$.

$1.2 \mathrm{ml}$ caffeine solution $\left(10 \mathrm{mg} \cdot \mathrm{mL}^{-1}\right)$ was applied to the skin surface in the donor cell and $320 \mu \mathrm{L}$ samples were withdrawn from the receiver compartment at 4, 6, 8, 20,24, 28, 32, 46, and 48 hours. The sampled volume was replaced with phosphate-buffered saline (PBS) after each sample was removed.

Each experiment was done in four fold per skin species.

\section{Analytical methods}

Caffeine concentrations were determined using an HPLC (high performance liquid chromatography) serie 1200 from Agilent Technologies GmbH (Waldbronn, Germany) and a 996 PDA (Photo Diode Array) detector from Waters GmbH (Eschborn, Germany). The lower limit of quantification of caffeine was $0.050 \mu \mathrm{g} \cdot \mathrm{mL}^{-1}$. The column used was a Waters Symmetry C18, 3.5 $\mu \mathrm{m}, 4.6 \times 75 \mathrm{~mm}$, supplied by Waters $\mathrm{GmbH}$ (Eschborn, Germany), set at $40^{\circ} \mathrm{C}$. The mobile phases were phosphate buffer pH 3.50 ( \pm 0.05) and acetonitrile run in gradient condition at a flow rate of $1.0 \mathrm{ml} . \mathrm{min}^{-1}$ (gradient profile: 0.0 min; buffer $/ A C N$ 90/10 => 2.5 min: buffer $/ A C N$
90/10 => 5.0 min: buffer $/ \mathrm{ACN} 40 / 60=>6.0 \mathrm{~min}:$ buffer $/ \mathrm{ACN} 40 / 60=>6.1 \mathrm{~min}$ : buffer $/ \mathrm{ACN} 90 / 10$ => $10.0 \mathrm{~min}$ : buffer $/ \mathrm{ACN} 90 / 10)$, and detection at $272 \mathrm{~nm}$. The retention time was 3.7 minutes.

\section{Calculations}

Apparent permeation coefficient was calculated using Eq. 1:

$$
P_{a p p}=\frac{d Q}{d t} \cdot \frac{1}{m_{0}} \cdot \frac{1}{A} \cdot V_{D}
$$

$P_{a p p}$ is the apparent permeation coefficient $\left(\mathrm{cm} . \mathrm{s}^{-1}\right)$ $d Q / d t$ is the steady state transport rate obtained by linear regression of the amount of test substance transported vs time $\left(\mu \mathrm{g} . \mathrm{s}^{-1}\right)$ $m_{0}$ is the initial mass of test substance in the donor compartment ( $\mu \mathrm{g})$ $A$ is the area of exposed skin $\left(\mathrm{cm}^{2}\right)$ and $V_{D}$ is the donor volume $\left(\mathrm{cm}^{3}\right)$

\section{Statistical methods}

Differences in cumulative transport through the skin samples were compared with a nonparametric Mann-Whitney U- test. All results are expressed as mean \pm standard deviation.

\section{Histology}

Human and reptile skin tissues (not thicker than $3 \mathrm{~mm}$ ) were fixed in $10 \%$ formalin at room temperature for 8 hours and then dehydrated in a grade series of ethanol baths $(70 \%$ ethanol for 1 hour, $95 \%$ ethanol for 1 hour twice, $100 \%$ 
ethanol for 1 hour twice). The tissue was cleared in xylene for 1 hour (2 times), then embedded in paraffin blocks. Paraffin sections were done at a thickness of 4 to $5 \mu \mathrm{m}$ from paraffin blocks. The obtained slides were allowed to dry overnight. The next day the slides were placed in a $55{ }^{\circ} \mathrm{C}$ oven for ten minutes to melt the paraffin. Deparaffinize was done by using two changes of Xylene for 5 minutes, two changes of $100 \%$ alcohol and $95 \%$ alcohol for 3 minutes each. The staining was performed by using hematoxylin. The mounted slides were examined using a Leica DM4000 B Microscope, and photographed by a Leica MC120HD HD Camera from Leica Mikrosysteme Vertrieb GmbH (Wetzlar, Germany).

\section{Results}

\section{Histology}

Like mammalian skin, reptile skin consists of two main layers: the epidermis at the surface and the dermis underneath.

Reptile epidermis (see figure $3 \mathrm{~A}$ ) is characterized by the presence of a unique thick, horny surface featured with epidermal scales. Integumentary glands are not abundant. Snake shed skin and human Stratum corneum present analogies. The tissue thickness is similar with 13-15 $\mu \mathrm{m}$ and 10-20 $\mu \mathrm{m}$ in respectively human and snake shed skin. The structure for keratin type a and $\beta$ ( $\beta$ : only reptiles and birds) as well as the lipid composition is comparable in both tissues $(2.0-6.5 \%$ in human
Stratum corneum and 6.0\% in snake shed skin) (12).

The main difference is that human epidermis has a dense Stratum corneum (see figure 3 B), with hairs present arising from hair follicles. In addition, in human skin, epidermal glands including sebaceous or sudoriferous glands are present.

Reptile epidermis is composed of three cell layers arranged from the bottom to the surface as follows (see figure 4A):

Stratum germinativum or basal layer composed of undifferentiated growing cells ensuring the renewal of the epidermis

Stratum intermedium or intermediate zone composed of cells in migration and producing keratin. The cells become flatter as they reach the surface.

Stratum corneum, the third layer of the epidermis, is constituted of three layers: an a keratin layer, a $ß$ keratin layer and the third layer named Oberhäutchen (13). These layers are composed of highly keratinized flat dead cells. a keratin is similar to the keratin in the composition of the hair in mammals. $§$ keratin is similar to the keratin in the composition of bird feather. These two layers provide flexibility to the epidermis, due to the a keratin helical structure, but also inflexibility, due to the $§$ keratin pleated sheet structure. The $\S$ keratin is predominant on the outer scale surface (providing the rigidity to ensure the protection function of the skin) and is attenuated on the inner scale surface and hinge region. In the hinge region of the scales, a keratin is more present, providing the elasticity to this area. The epidermis of the belly

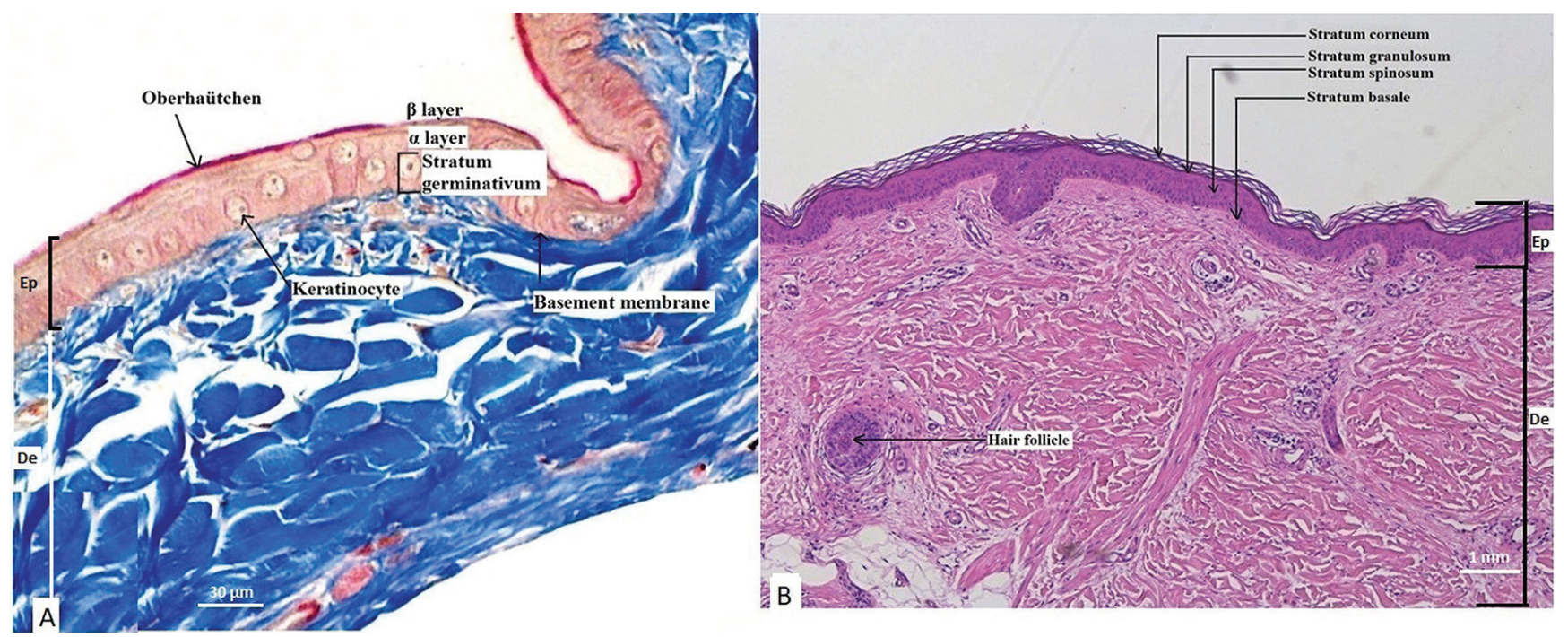

Figure 3: Photomicrograph of histological sections of reptile and human skins. A. reptile dorsal skin X400.

B. human skin, X5. Stratum lucidum is not visible. Ep: Epdermis, De: Dermis 

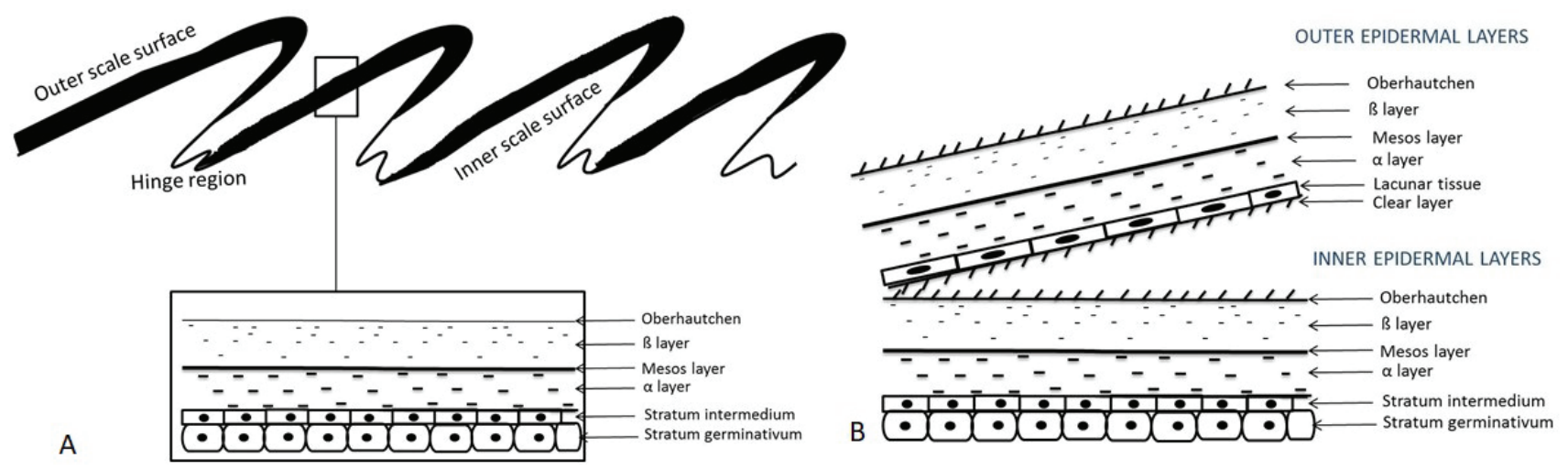

Figure 4: Diagrammatic representations of snake skin. A. transverse section of snake skin (adapted from Roberts 1986) (14). B. Terminal differentiation in the shedding cycle stage 5 and 6

is composed of a thicker and keratin rich layer to insure the protection against roughness of the ground or other substrate. Between these keratin layers ( $\alpha$ and $§)$ appears a polar lipid layer (named mesos layer), which plays a role in the permeability of the skin to water, gases, and other molecules.

The dermis located below the epidermis is at least four times as thick, and consists of a connective tissue containing abundant collagen fibers arranged in a reticular pattern, as well as blood vessels, sensorial receptors, and nerves. The main difference compared to mammalian skin is the lack of glands, follicular hairs, and arrector muscles. The hypodermis is mainly composed of a layer of abundant subcutaneous adipose tissue and overlies a deep fascia and skeletal muscle fibers.

\section{Physiological molting (Ecdysis)}

Molting can be a continuous renewal as seen in mammalian epidermis. This mode is adopted by most chelonians and crocodilians. The other mode is the episodic shedding of epidermis, as adopted by squamate reptiles.

Molting is a physiological mechanism dependent on the thyroid hormones. These hormones are able to stimulate the molting process in saurians, while they inhibit the process in ophidians.

The sloughing cycle of the multilayered epidermis can be divided into two phases: resting phase and renewal phase (15).

The resting phase is represented by stage 1 . It starts after the molt of the animal, and can be further divided into immediate post-shedding phase, the perfect resting phase and the prerenewal phase or late resting phase. The duration varies from a couple of days to months.
The renewal phase goes from stage 2 to stage 6 .

The stage 2 is characterized by an important multiplication of cells in the Stratum germinativum. The process leads to the formation of an intraepidermal shedding layer. The skin becomes dull. The beginning of the renewal phase takes about 5-7 days.

In the stage 3 , the new generated cells undergo a differentiation/keratinization process. Two pathways are used, a and $\beta$, leading to cells containing, respectively, $a$ and $\beta$ keratin. The skin appears very dull and snake eyes are opaque. The duration of this phase is about 3-4 days.

The stage 4 is defined by the production of a new epidermis. The layers of this outer epidermis are constituted of cells, differentiated and keratinized, distributed in an outer Oberhäutchen, $\beta$ layer, mesos layer, a layer, lacunar tissue, and a clear layer. The remaining inner epidermal layers consists of an inner Oberhäutchen, inner $\beta$ layer, inner mesos layer, as well as a non completed a and basal layer. This step takes about 5 to 10 days.

In the stage 5 (see figure 4B), the area between the 2 generations of epidermis (outer epidermal generation and inner epidermal generation) will be filled by lymph and enzymes. The skin and eyes become clear and shiny. The shedding of the old epidermis begins 3-4 days after skin becomes clear.

The stage 6 is the ultimate step of the ecdysis process, consisting of the separation of the outer epidermis or old Stratum corneum from the cleavage area. The two generations of epidermis will be separated. After the shedding, the skin becomes harder. 
Ex vivo transport of caffeine through snake shed and human skins

Figure 5 presents the cumulative caffeine transport over time on each snake shed skin. The cumulative amount of caffeine increased linearly with time through the dorsal and ventral shed skin of all 3 species, corresponding to a typical passive diffusion. After 48 hours, the cumulative amount of caffeine transported across the Lampropeltis dorsal skin was about twice the amount transported across Boa dorsal skin, and about 3.5 times higher than the amount across Python dorsal skin (see table 1).

The most permeable was the Lampropeltis skin, with ventral as permeable as dorsal (no statistical difference, $\mathrm{p}>0.05$ ). Boa skin displayed intermediate permeability with ventral skin more permeable than dorsal (statistically different, $\mathrm{p}<0.05)$. Python skin was the least permeable with dorsal and ventral skin producing identical results.

Figure 5: Ex vivo percutaneous transport of Caffeine through shed skins. The cumulative transport $\left(\mu \mathrm{g} . \mathrm{cm}^{-2}\right)$ was calculated by the caffeine concentration determined by HPLC at each sampling time point from the receptor medium. The experiments were performed in four-fold for each skin (ventral and dorsal shed skin of the 3 snake species). Data are shown as mean values of the 4 determinations

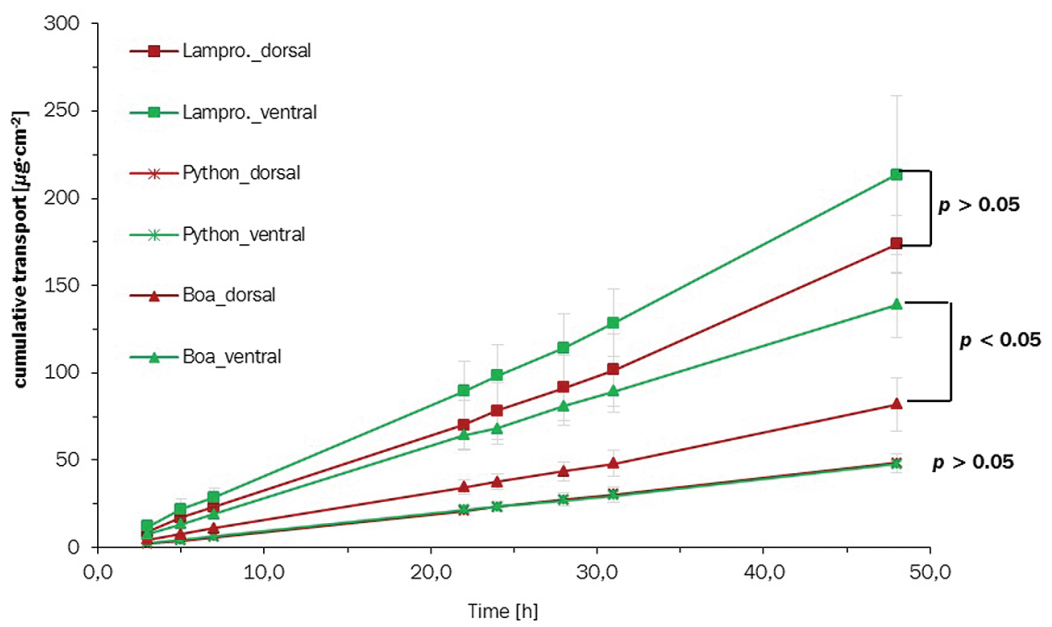

Table 1: Cumulative transport of caffeine after 48 hours, and Papp values on snake shed skins samples ex vivo. Values are presented as mean $\pm \mathrm{SD}$

\begin{tabular}{lccccc}
\hline Membrane & $\begin{array}{c}\text { Cumulative transport after } \\
\text { 48 hours }\left(\mu \mathrm{g} \cdot \mathrm{cm}^{-2}\right)\end{array}$ & $\mathrm{SD}\left(\mu \mathrm{g} \cdot \mathrm{cm}^{-2}\right)$ & $\begin{array}{c}\text { Papp values } \\
(\mathrm{cm} / \mathrm{s})\end{array}$ & $\mathrm{SD}(\mathrm{cm} / \mathrm{s})$ & $\mathrm{RSD}(\%)$ \\
\hline Lampropeltis dorsal & 173.71 & 16.73 & $8.91 \mathrm{E}-08$ & $1.76 \mathrm{E}-08$ & 19.75 \\
Lampropeltis ventral & 213.44 & 45.39 & $1.23 \mathrm{E}-07$ & $2.62 \mathrm{E}-08$ & 21.26 \\
Python dorsal & 48.36 & 5.26 & $2.79 \mathrm{E}-08$ & $3.04 \mathrm{E}-09$ & 10.87 \\
Python ventral & 47.73 & 1.13 & $2.76 \mathrm{E}-08$ & $6.56 \mathrm{E}-10$ & 2.38 \\
Boa dorsal & 82.08 & 15.37 & $4.75 \mathrm{E}-08$ & $9.89 \mathrm{E}-09$ & 20.79 \\
Boa ventral & 138.95 & 18.41 & $8.05 \mathrm{E}-08$ & $1.07 \mathrm{E}-08$ & 13.25 \\
\hline
\end{tabular}

Figure 6: Analyses of apparent permeability rate of caffeine transported in acceptor compartment (Papp) through a normalized surface of shed skin (dorsal and ventral parts) of the 3 snake species, and human skin. The mean Papp values of 4 determinations are represented $\left(\mathrm{cm} . \mathrm{s}^{-1}\right)$. Statistically significant differences are shown by brackets (Mann-Whitney U test)

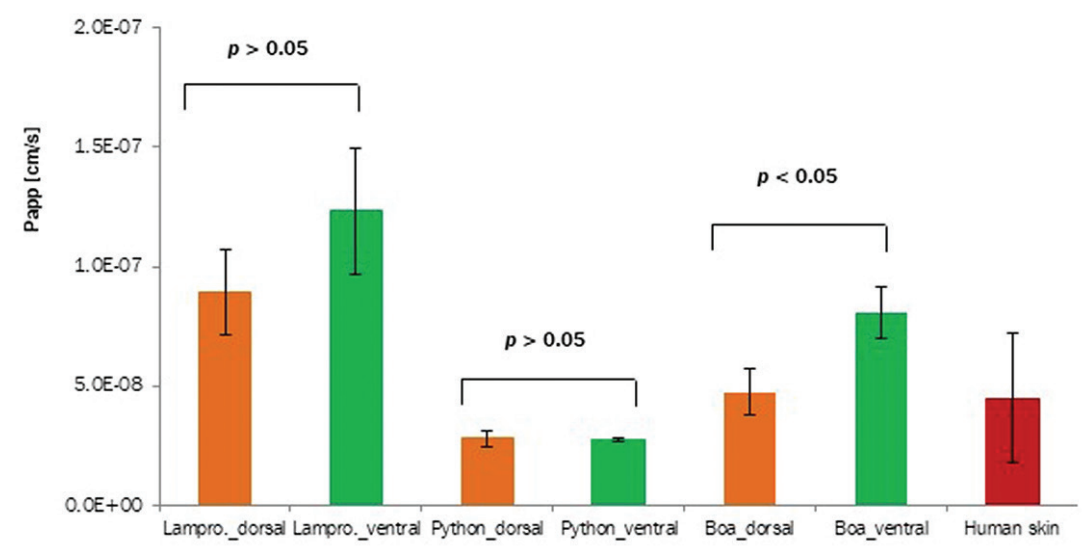


Table 2: Comparison of apparent permeability coefficients for caffeine through 23 different dermatomized skin specimens with intact SC. In bold are the snake shed skins

\begin{tabular}{|c|c|c|c|}
\hline Skin number & Mean $\mathrm{P}_{\text {app }}\left[\mathrm{cm} \cdot \mathrm{s}^{-1}\right]$ & $\mathrm{SD}\left[\mathrm{cm} \cdot \mathrm{s}^{-1}\right]$ & RSD [\%] \\
\hline 0897-01-1017 & $1.31 \mathrm{E}-08$ & $9.17 \mathrm{E}-10$ & 7.00 \\
\hline 557-01-1113 & $1.45 \mathrm{E}-08$ & 4.93E-09 & 34.00 \\
\hline 0880-01-0717 & $1.73 \mathrm{E}-08$ & $3.11 \mathrm{E}-09$ & 18.00 \\
\hline 0878-01-0717 & $1.76 \mathrm{E}-08$ & 3.17E-09 & 18.00 \\
\hline 0722-01-1015 & $1.93 \mathrm{E}-08$ & 4.05E-09 & 21.00 \\
\hline $559-01-1213$ & $2.04 \mathrm{E}-08$ & $1.63 \mathrm{E}-09$ & 8.00 \\
\hline 0875-01-0617 & $2.18 \mathrm{E}-08$ & $6.54 \mathrm{E}-09$ & 30.00 \\
\hline 0901-01-1117 & $2.38 \mathrm{E}-08$ & $3.81 \mathrm{E}-09$ & 16.00 \\
\hline $150-01-1203$ & $2.54 \mathrm{E}-08$ & $1.42 \mathrm{E}-08$ & 56.00 \\
\hline Python ventral & 2.76E-08 & $4.86 \mathrm{E}-09$ & 2.38 \\
\hline Python dorsal & 2.79E-08 & $6.18 \mathrm{E}-09$ & 10.87 \\
\hline 0724-01-1015 & $3.04 \mathrm{E}-08$ & $7.58 \mathrm{E}-09$ & 16.00 \\
\hline 0898-01-1117 & $3.25 \mathrm{E}-08$ & $6.99 \mathrm{E}-09$ & 19.00 \\
\hline 0737-01-1115 & $3.99 \mathrm{E}-08$ & $1.04 \mathrm{E}-08$ & 19.00 \\
\hline 0747-01-0116 & $4.11 \mathrm{E}-08$ & $9.61 \mathrm{E}-09$ & 17.00 \\
\hline 537-01-1013 & $4.17 \mathrm{E}-08$ & $3.38 \mathrm{E}-09$ & 25.00 \\
\hline Boa dorsal & 4.75E-08 & $2.32 \mathrm{E}-08$ & 20.79 \\
\hline 062-01-0701 & $5.34 \mathrm{E}-08$ & $2.12 \mathrm{E}-08$ & 18.00 \\
\hline 060-01-0601 & $5.63 \mathrm{E}-08$ & $3.21 \mathrm{E}-08$ & 6.00 \\
\hline 0826-01-1116 & $5.96 \mathrm{E}-08$ & $2.50 \mathrm{E}-08$ & 39.00 \\
\hline 0768-01-0416 & $6.42 \mathrm{E}-08$ & $2.35 \mathrm{E}-08$ & 33.00 \\
\hline Boa ventral & 8.05E-08 & $2.15 \mathrm{E}-08$ & 13.25 \\
\hline 059-01-0601 & $8.24 \mathrm{E}-08$ & $2.84 \mathrm{E}-08$ & 39.00 \\
\hline 0728-01-1115 & 8.34E-08 & $9.17 \mathrm{E}-10$ & 30.00 \\
\hline $153-01-0104$ & $8.41 \mathrm{E}-08$ & 4.93E-09 & 28.00 \\
\hline Lamprop. dorsal & 8.91E-08 & $3.11 \mathrm{E}-09$ & 19.75 \\
\hline 0887-01-0917 & $9.35 \mathrm{E}-08$ & $3.17 \mathrm{E}-09$ & 23.00 \\
\hline 061-01-0701 & $9.78 \mathrm{E}-08$ & 4.05E-09 & 29.00 \\
\hline Lampropeltis ventral & $1.23 E-07$ & $1.63 \mathrm{~F}-09$ & 21.26 \\
\hline
\end{tabular}

The mean permeation coefficient (mean $\mathrm{P}_{\text {app }}$ ), was derived from slope of the linear portion of the cumulative transport curves (see figure 6, table 1).

Table 2 provides an overview of caffeine permeability through 23 human dermatomed skin specimens, including the Papp values obtained with the snake shed skins
All the Papp values on shed skins are within the same magnitude compared with data obtained on human dermatomed skins from 23 different donors under the same conditions using the same methods (see table 2). 


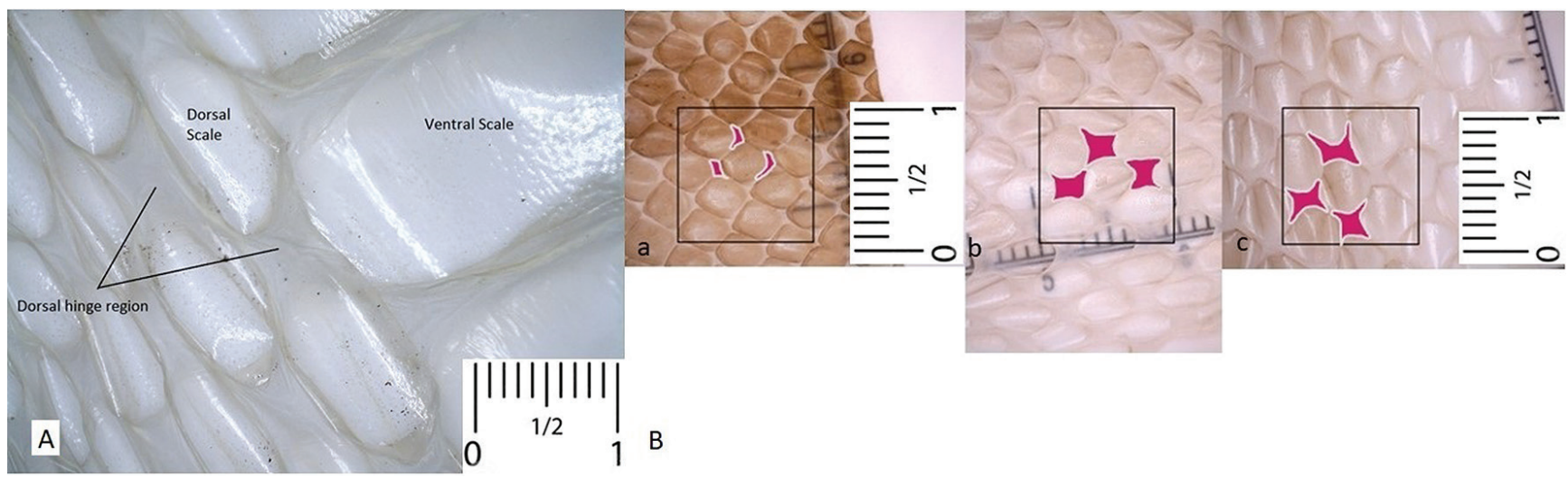

Figure 7: Photographs of scales and hinge areas of not hydrated shed snake skins. A. dorsal and ventral scales, and hinge areas of Boa (Epicrates maurus colombianus). B. dorsal shed skin of the 3 snake species. a. Python regius, b. Epicrates maurus colombianus, c. Lampropeltis triangulum campbelli. Red color indicates the hinge area. Scales refer to 1 centimeter

\section{Discussion}

The difference in permeability of caffeine between the snake shed skins is difficult to explain. The difference in size and shape of the scales, particularly in the available hinge region, may be a factor. The hinge region, which is constituted mainly of a keratin, provides the elasticity of this area. Furthermore, the region is always considerably thinner than the scale regions composed of a thicker and (ß) keratin rich layer (see figures $4 \mathrm{~A}$ and $7 \mathrm{~A}$ ). Hinge areas are therefore considered to be more permeable. In the Lampropeltis and Boa dorsal skins, these regions are much larger than in Python (see figure 7B). Thus, more caffeine formulation is in contact with these areas, explaining the difference in permeability.

The mean human skin $\mathrm{P}_{\text {app }}$ values range from $1.31 \mathrm{E}-08$ to $9.38 \mathrm{E}-08 \mathrm{~cm} \cdot \mathrm{s}^{-1}$. The variation observed can be largely attributed to natural human variability in dermal absorption. Except for Lampropeltis ventral skin, the caffeine permeation behavior was similar between snake shed skins tested and human skin $(\mathrm{p}=0.594$ and $\mathrm{p}=0.531$ with respectively python dorsal and ventral, $p=0.762$, and $p=0.060$ with respectively Boa dorsal and Boa ventral). Shed skins from one specimen of each snake species were used for the experiments, and therefore the lack of variability may be an explanation for the difference observed with Lampropeltis ventral skin.

Even if the snake shed skin only consisted of a part of epidermis (only Stratum corneum), in comparison to human dermatomed skin, which contains the complete epidermis and a part of the dermis, the results show that Stratum corneum functions as the main barrier and is sufficient to investigate permeation of markers. Furthermore, at this thickness, the resistance of the dermis, present in dermatomed human skin, to overall skin permeation can be ignored (16) (e.g. Papp value of Caffeine through human epidermis sheets is $6.00 \mathrm{E}-08 \pm 0.04 \mathrm{~cm} \cdot \mathrm{s}^{-1}(17)$.

Ngawhirunpat (2006) (6) compared the in vitro percutaneous absorption of hydrophilic molecules using shed snake skin of Pantherophis obsoletus and human skin. In shed snake skin, the absorption rates of hydrophilic molecules were until six times lower than in human skin. Ngawhirunpat concluded that the shed snake skin contained significantly less water than human Stratum corneum. Therefore, the lower permeability observed in shed snake skin for hydrophilic molecules might be caused by a lower size and/ or number of pores in skin layers. But according to Torri (2014) (18), based on the analyses of shed skins from four snake species, depending of their taxon and ecology, the snakes have developed species-specific layers of lipids with different structures and composition for the regulation of water permeability. Therefore, in snake skin, the water absorption changes among species living in different climates and habitats. This may explain a difference of permeability for hydrophilic molecules among the snake skins. The results obtained by Ngawhirunpat on Pantherophis obsoletus cannot be generalized, and therefore, cannot automatically be transposed to other snake species. The specific lipid structures in the snakes from predominantly dryland habitats such as Python regius can protect 
the snake from water lost at high temperatures, and may explain the difference seen in lowest absorption of caffeine in comparison to Epicrates maurus colombianus, which come from a wetland/ rainforest habitat and have a skin that is more permeable to hydrophilic molecules.

Our results with shed skins from Python regius, Lampropeltis triangulum campbelli, Epicrates maurus colombianus, are in non-correspondence to Ngawhirunpat's findings, when using caffeine as hydrophilic drug, which displays similar percutaneous absorption behavior on human skin. Therefore, depending of the snake species of skin used, and their habitat (desertic, rainforest, etc.) the permeability behavior of hydrophilic drug can be different or similar to human skin.

In addition, Klein (2012) (19) confirmed that the epidermis architecture and material properties of the snake skin may change in relation to the snakes' habitats. Particularly important are the differences observed in the structure of the mesos layer between the species, which play a role in the permeability of the skin to water, gases, and molecules including caffeine.

\section{Conclusion}

All three species of snake shed skins displayed different characteristics as caffeine diffusion membranes. The possible variability among snake species may be due to differences observed in skin composition. Except for the ventral skin of Lampropeltis triangulum campbelli, the caffeine permeation obtained with all snake shed skins investigated was similar to that of human skin. Snake shed skin seems to be an interesting tool to simulate human skin for studies investigating in vitro percutaneous absorption of caffeine. It may help to select the best candidate from several newly developed cosmetic formulations containing this active pharmaceutical ingredient.

Additional hydrophilic and lipophilic molecules should be investigated to validate the snake shed model. More snake species as well as the interindividual variability must be evaluated.

For future testing of molecules, the main challenge will be to select the most appropriate species of snake whose skin resembles human skin.

\section{Acknowledgements}

This study was supported by Dr. Hyun Ik Kim (New Jersey), who provided a full review of the manuscript. Histological works were performed by Kai Emrich from Institut für Pathologie Saarbrücken-Rastpfuhl (Germany). Thanks to Professor Ahmed Aly Ahmed Allam Zoology Department, Faculty of science, Beni-Suef University, Beni-Suef 62511, Egypt, for providing the picture of histological section of reptile dorsal skin

\section{References}

1. TsangVL, Bhatia SN. Three dimensional tissue fabrication. Adv Drug Deliv Rev 2004; 56(11): 1635-47. doi:10.1016/j.addr.2004.05.001

2. Kim JB. Three-dimensional in vitro tissue culture models of breast cancer-a review. Breast Cancer Res Treat 2004; 85(3): 281-91. doi:10.1023/B:BREA.0000025418.88785.2b

3. Kolar R. Animal experimentation. Sci Eng Ethics 2006; 12(1): 111-22. doi:10.1007/s11948006-0011-1

4. EMA Guideline on the principles of regulatory acceptance of 3Rs (replacement, reduction, refinement) testing approaches. EMA/ CHMP/CVMP/JEG-3Rs/450091/2012. London : Euoropean Medicines Agency, 2016. https:// www.ema.europa.eu/en/documents/scientific-guideline/guideline-principles-regulatory-acceptance-3rs-replacement-reduction-refinement-testing-approaches_en (25. Sept. 2019)

5. OECD. Test no. 428: Skin absorption: In vitro method. In: Guidelines for the testing of chemicals, Section 4: Health effects. Paris : OECD Publishing, 2004. doi:10.1787/9789264071087-en (9. July 2018)

6. Ngawhirunpat T, Panomsuk S, Opanasopit P, Rojanarata T, Hatanaka T. Comparison of the percutaneous absorption of hydrophilic and lipophilic compounds in shed snake skin and human skin. Pharmazie 2006: 61(4): 331-5.

7. Higuchi T, Kans L. Method for in vitro determination of transdermal absorption: [patent number US4771004, Sept 13, 1988].

8. Haigh JM, Beyssac E, Chanet L, Aiache JM. In vitro permeation of progesterone from a gel through the shed skin of three different snake species. Int J Pharm 1998; 170(2): 151-6. doi:10.1016/S0378-5173(98)00064-7 
9. Herman A, Herman AP. Caffeine's mechanisms ofaction andits cosmeticuse. Skin Pharmacol Physiol 2013; 26: 8-14. doi:10.1159/000343174

10. Caffeine. In: DrugBank. Ottawa : Canadian Institutes of Health Research. https://www.drugbank.ca/drugs/DB00201 (10. Jan. 2020)

11. Balamurugan M, Weli MA, Edwards G, Al-Harrsi A, Al-Kharusi Z. In vitro permeation studies of commercially available diclofenac sodium gel (sample analysis using LC-MS/MS) through the two different shed snake skins obtained from various regions of sultanate of Oman: a pilot study. Latin Am J Pharm 2013; 32 (7): 1069-73.

12. Rigg PC, Barry BW. Shed snake skin and hairless mouse skin as a model membrane for human skin during permeation studies. J Invest Dermatol Baltimore 1990: 94(2): 235-40. doi:10.1111/1523-1747.ep12874561

13. Mader DR. Reptile medicine and surgery. $2^{\text {nd }}$ ed.. St. Louis : Saunders, 2006: $1242 \mathrm{p}$.

14. Roberts JB. Use of squamate epidermis in percutaneous absorption studies: a review. J Toxicol Cutaneous Ocul Toxicol 1986; 5(4): 319-24. doi:10.3109/15569528609036305
15. Chang C, Wu P, Baker U, Maini PK, Alibardi L, Cheng-Ming C. Reptile scale paradigm: Evo-Devo pattern formation and regeneration. Int J Dev Biol 2009: 53: 813-26. doi:10.1387/ ijdb.072556cc

16. Hatanaka $T$, Inuma $M$, Sugibayashi $K$, Morimoto Y. Prediction of skin permeability of drugs I: Comparison with artificial membrane. Chem Pharm Bull 1990; 38: 3452-9. htpp://doi. org/ $10.1248 / \mathrm{cpb} .38 .3452$

17. Schäfer-Korting $M$, Bock U, Gamer $A$, et al. Reconstructed human epidermis for skin absorption testing: results of the German prevalidation study. ATLA 2006; 34: 283-94. doi: $10.1177 / 026119290603400312$

18. Torri C, Mangoni A, Teta R, et al. Skin lipid structure controls water permeability in snake molts. J Struct Biol 2014; 185: 99-106. doi:org/10.1016/j.jsb.2013.10.007

19. Klein MCG, Gorb SN. Epidermis architecture and material properties of the skin of four snake species. J R Soc Interface 2012; 9: 314055. doi:10.1098/rsif.2012.0479

\title{
PRIMERJAVA HISTOLOŠKE ZGRADBE TER PERKUTANE ABSORPCIJE KOFEINA IN VITRO V LEVKU KAČ IN ČLOVEŠKI KOŽI
}

\author{
M. Sacha, N. Weisbach, A.S. Pöhler, N. Demmerle, E. Haltner
}

Povzetek: Koža (človeškega ali živalskega izvora) se pogosto uporablja kot orodje za proučevanje biofarmacevtskih lastnosti topikalnih zdravil. Koža kač bi lahko bila uporabna alternativa drugim živalskim kožam in človeški koži pri oceni sposobnosti prenosa zdravil preko kože. Cilj študije je bil histološka primerjava človeške in kačje kože ter primerjava absorpcije kofeina kot hidrofilne modelne snovi na levkih kač iz dorzalnega in ventralnega področja treh različnih vrst kač: kraljevega pitona (Python regius), mavričnega udava (Epicrates maurus colombianus), mlečne kače (Lampropeltis triangulum campbelli). Kačja koža je histološko podobna človeški glede debeline in sestave roženi plasti (stratum corneum). Glavna prednost levitve kač je, da se dogaja večkrat, kar omogoča pridobitev več levkov, ki se jih lahko pridobi brezžrtvovanja živali. Rezultati so pokazali, da se je skupna količina kofeina sčasoma linearno povečevala v dorzalnih in ventralnih levkih pri vseh treh vrstah kač, razen na na ventralnem področju levka mlečne kače (Lampropeltis triangulum campbellI), pri katerem je bila prehodnost kofeina podobna kot pri prehodu skozi človeško kožo.

Ključne besede: kofein; transdermalno; levek; in vitro; kača; topikalni pripravek 